\title{
Morphological characteristics of Taurus cedar seedlings produced in Cankiri forest nursery
}

\author{
Özlem EKEN*, Nuri ÖNER \\ Çankırı Karatekin University, Faculty of Forestry, Çankırı, TURKEY \\ *Corresponding author: ozlemeken@karatekin.edu.tr
}

Received Date: 13.01.2017

Accepted Date: 09.06.2017

\section{Abstract}

Aim of study: There are many studies related to determination of the quality seedlings use as affecting the success of reforestation studies. In general, the morphological properties are used in evaluation of the seedling quality. The aim of this study was to evaluate seedling quality of Taurus cedar seedlings.

Area of study: This study was to evaluate Taurus cedar seedlings produced at Kenbag forest nursery in Çankırı province, Central Anatolia, Turkey.

Material and Methods: Four groups of Taurus cedar seedlings were used $(1+0$ and $1+1$ aged and tubed seedlings of Mersin (Mut), Konya (Ermenek) and Antalya (Kumluca) origins). Morphological properties such as seedling height $(\mathrm{cm})$, root collar diameter $(\mathrm{mm})$, dry root weight $(\mathrm{g})$, stem dry weight, and number of lateral roots were measured on seedlings with different origins and ages. . Data were evaluated with one-way ANOVA statistic.

Main results: Results showed that both seedlings of Mersin (Mut) and seedlings of Antalya (Kumluca) origins had better development than seedlings of Konya (Ermenek) origin. In addition Taurus cedar seedlings of Konya $(1+1)$, Mersin $(1+1)$ and Antalya $(1+1)$ origins were in the first (I) class in terms of height according to the Coniferous Trees' Seedling Standards; TS 2265/February 1998.

Research highlights: Morphological properties of seedlings are affected by cultural processes. We can suggest that a certain irrigation interval should be determined for Cankiri region.

Keywords: Origin, Reforestation, Seedling quality, Taurus cedar, Tubed seedling

\section{Çankırı orman fidanlığında yetiştirilen Toros sediri fidanlarının}

\section{morfolojik karakteristikleri}

Özet

Çalışmanın amacı: Ağaçlandırma çalışmalarının başarısını etkileyen kaliteli fidan kullanımıyla ilgili çok sayıda çalışma mevcuttur. Yapılan çoğu çalışmada, fidan kalitesini belirlemede genellikle morfolojik özellikler kullanılmaktadır. Bu çalışmanın amacı Toros sediri türlerinin fidan kalite değerlendirmesidir.

Çalışma alanı: Çalışmada Çankırı ilinin merkezinde yer alan Kenbağ orman fidanlığında yetiştirilen Toros sediri fidanları değerlendirilmiştir.

Materyal ve Yöntem: Çalışmada, orijinleri ve yaşları farklı olan fidanlar saptanmış ve bu fidanların morfolojik özellikleri ölçülmüştür. Ölçülen morfolojik özellikler; fidan boyu $(\mathrm{cm})$, kök boğazı çapı $(\mathrm{mm}$, kök kuru ağırlığı (g), sak kuru ağırlığı (g), ve yan kök sayısıdır. Çalışmada, Toros Sediri fidanlarında 4 grup belirlenmiştir. Bunlar; Toros sedirinde Mersin (Mut), Konya (Ermenek) ve Antalya (Kumluca) orijinlerine ait $1+0 / 1+1$ yaşında tüplü fidanlardır. Veriler SPSS istatistik programında tek-yön ANOVA analiziyle değerlendirildi.

Sonuçlar: Sonuçlarda Mersin (Mut) ve Antalya (Kumluca) orijinli fidanlar Konya (Ermenek) orijinli fidanlara göre daha iyi gelişim göstermiştir. Konya (1+1), Mersin $(1+0)$ ve Antalya $(1+1)$ sedir fidanları TS 2265/Şubat 1988 İğne Yapraklı Ağaç Fidanları Standardına göre değerlendirildiğinde boy bakımından I. sinif bulunmuştur.

Araştırma vurguları: Kültürel fidanlık uygulamaları fidanların morfolojik özelliklerini etkilemektedir. Çankırı bölgesi için belli bir sulama aralığının belirlenmesi önerilebilir.

Anahtar Kelimeler: Orijin, Ağaçlandırma, Fidan kalitesi, Toros sediri, Tüplü fidan 


\section{Introduction}

The total natural forest area of $C$. libani is 482.39 ha $(2.16 \%)$ in Turkey and 247.162 ha of this area are normal closure and 235.229 ha are destroyed closure (Anon. 2015). Taurus cedar is widely used either in its natural distribution area or in degraded and unproductive outside its natural area since its easily adaptation to difficult conditions, and resistance to frost, fire, and extreme temperatures. It is used widely in the Mediterranean region because of its resistance to high temperature, drought and frost (Yahyaoglu and Genc, 1990). Besides, Taurus cedar has tap-root system; it is also resistant to drought. Therefore, it is one of the most preferred species in reforestation of arid and semi-arid areas (Boydak and Caliskan, 2014).

Reforestation is one of the main activities of forestry; seedling material used in reforestation highly affects the success of planting and plant development (Urgenc, 1986). Use of quality seedlings with high adaptation ability may increase the success of reforestation studies (Davis and Jacobs, 2005). Duryea (1985) stated that "seedling evaluations need to be refined so that they predict not only growth as well as survival but also performance of specific seedling lots on particular sites".

Seedling quality should be evaluated according to site conditions and aim of reforestation studies. Using quality seedlings is more important for reforestation studies especially in Central, Southeastern, and Eastern Anatolia which are characterized cold-arid and hot-arid areas (Genc and Yahyaoglu, 2007). Mattsson (1996) stated that seedlings, which are suitable for the purpose are quality seedlings. Morphological characteristics have been used widely to assess seedling quality, because of their ease of measurement. The major morphological attributes are age, height, root collar diameter, bud length, stem: root ratio, stem weight and root weight (Genc and Yahyaoglu, 2007). Thompson (1985)stated that height and root collar diameter is practiced by many forest nurseries as a basis for separating out stock of poor quality. Owing to ease of most morphological parameters' measurements makes them the most popular method for measuring seedling quality. A morphological index is a combination of two or more morphological measurements. They are generally designed to serve one of two purposes: the first one is to describe an abstract attribute of a seedling, such as balance and sturdiness; and the second one is to determine the relative importance of the morphological measurements by combining them into an index that more closely corresponds to field performance than any individual parameter (Thompson, 1985). Morphological characteristics, specifically height and stem diameter, currently provide the best estimation of seedling performance after outplanting. Diameter is a much better predictor of survival than height growth (Mexal and Landis, 1990).

In this study we assessed the quality of the Taurus cedar seedlings reared under forest nursery conditions. In this regard, we evaluated quality of seedlings with different ages and origins using their mophological varibles.

\section{Material and Methods}

This study was carried out at Kenbag forest nursery in Cankiri, located $40^{\circ} 34^{\prime}$ North latitude and $33^{\circ} 30^{\prime}$ East longitudes in the north of Central Anatolian Region of Turkey (Figure 1). Research area is located at $6 \mathrm{~km}$ north of Cankiri city center and covers approximately 34.8 ha. Elevation from sea level is $750 \mathrm{~m}$ and slope is $2 \%$ at the eastwest direction at the forest nursery. The climate in the region is semi-arid and annual temperature, humidity, and rainfall is 11.4 ${ }^{\circ} \mathrm{C}, 63.2 \%$, and $418 \mathrm{~mm}$, respectively (Anon. 2014).

Soils of Kenbag forest nursery is clayloam $(50.6 \%)$. The reaction of the soils $(\mathrm{pH})$ 7.67 and $\mathrm{CaCO}_{3}$ content is $4.91 \%$. In addition according to water class analysis, irrigation water is $" \mathrm{C}_{3} \mathrm{~S}_{1}$ ".

We assessed 400 Taurus cedar seedlings in 4 groups. The groups included 2 different ages $(1+0$ and $1+1)$ and container seedlings. The seedlings were belonged to Mersin (Mut), Konya (Ermenek), and Antalya (Kumluca) origins. 


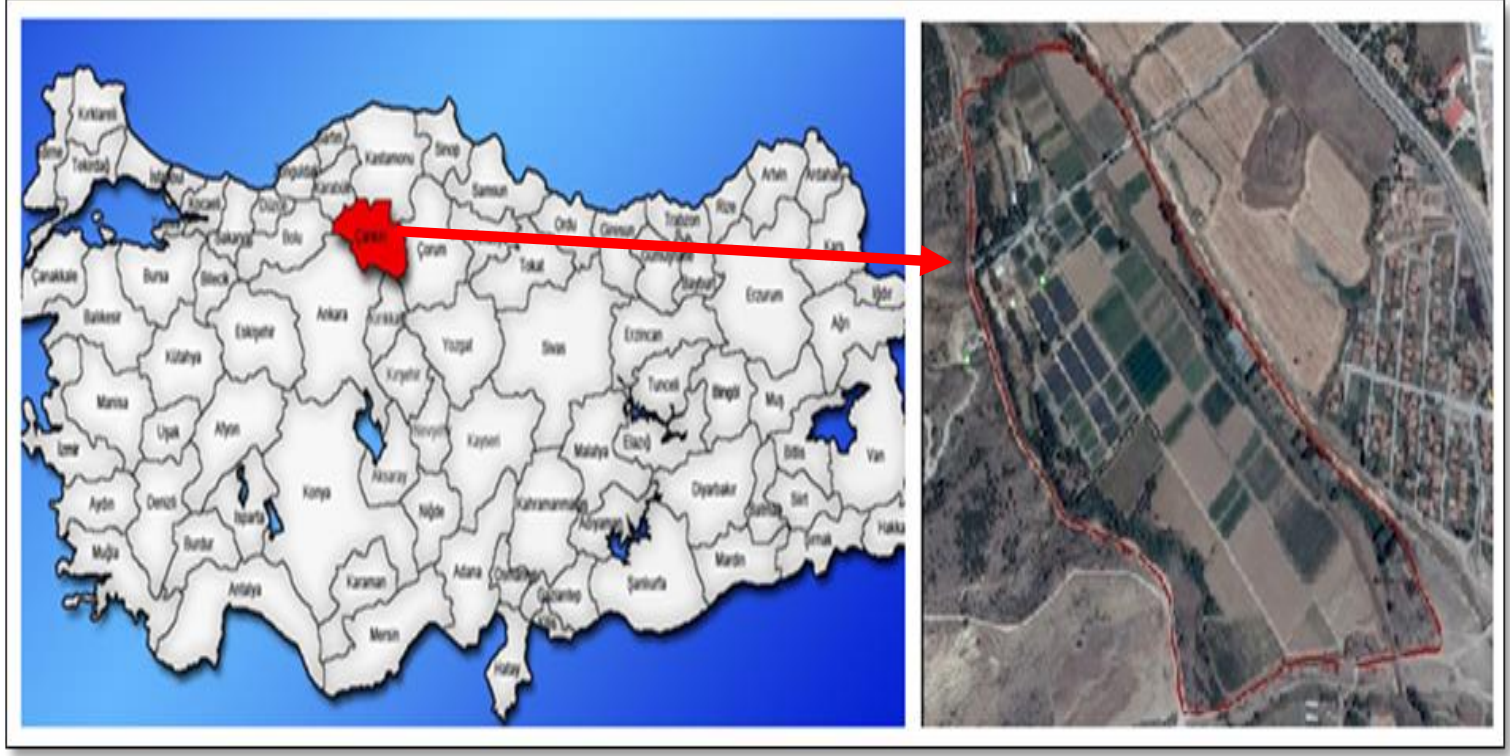

Figure 1. Location of the study area at $33^{\circ} 30^{\prime} \mathrm{E}-40^{\circ} 34^{\prime} \mathrm{N}$ on Turkey map (Anon. 2016)

Table 1. Age and origin of seedlings used

\begin{tabular}{ccccc}
\hline Species & Age & $\begin{array}{c}\text { Directorate of } \\
\text { regional forestry }\end{array}$ & $\begin{array}{c}\text { Department of } \\
\text { forestry }\end{array}$ & $\begin{array}{c}\text { Seed stand number and } \\
\text { date }\end{array}$ \\
\hline Cedrus libani & $1+0 / 1+1$ & Konya & Ermenek & TTS 4280-2013 \\
Cedrus libani & $1+0$ & Mersin & Mut & TTS 2686-2014 \\
Cedrus libani & $1+1$ & Antalya & Kumluca & TTS-1016-2013 \\
\hline
\end{tabular}

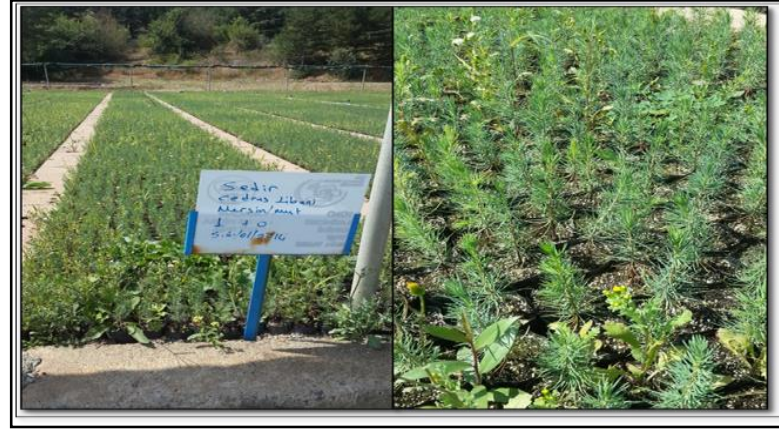

$\mathrm{a}$

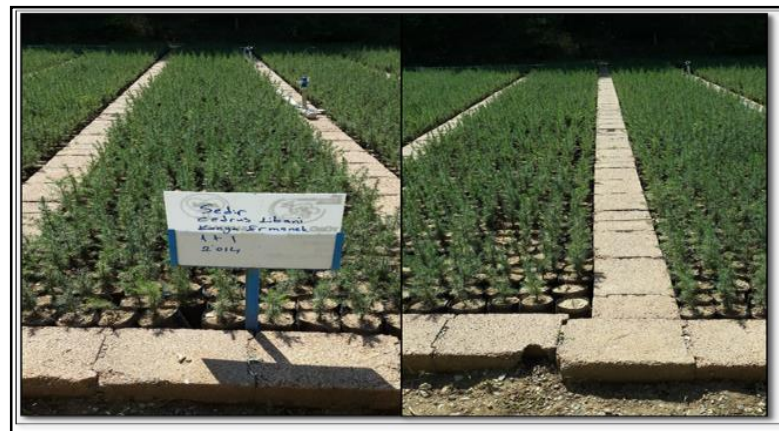

$\mathrm{c}$
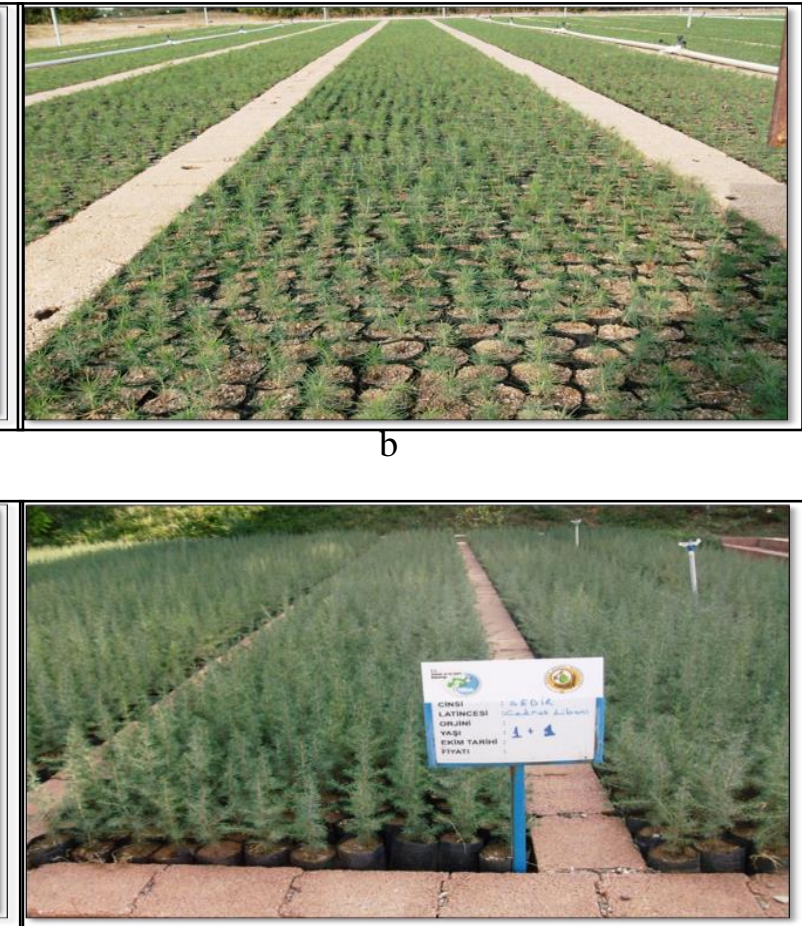

$\mathrm{d}$

Figure 2. Seedlings which used in this study (a; $1+0$ aged-Mersin origin, b; $1+0$ aged-Konya, c; $1+1$ aged-Konya, d; $1+1$ aged-Antalya) 
We measured height and root collar diameter of seedlings with a ruler with 0.1 $\mathrm{cm}$ sensitivity and a caliper with $0.1 \mathrm{~mm}$ sensitivity. We selected four samples randomly in each group for laboratory analyses.

Firstly, samples of seedlings were cleaned, washing with tapwater, and then numbers of lateral roots between root collar and $15 \mathrm{~cm}$ depth was determined. Secondly, we measured fresh weight of roots and stems. Thirdly, seedlings were dried for 24 hours in oven at $105^{\circ} \mathrm{C}( \pm 2)$ of constant temperature, and then root and stem dry weights were measured.

The data were evaluated using one-way ANOVA at 5\% level of significance. In addition, correlation analysis was performed to determine the relationships between measured parameters in the origins.

\section{Results}

Descriptive statistics of morphological properties for measured Taurus cedar seedlings (Eken, 2015) are given in Tables 2 and 3 .

Table 2. Morphological characteristics of $1+0$ aged and tubed seedlings of Mersin and Konya origins

\begin{tabular}{lcccccccc}
\hline & \multicolumn{3}{c}{ Mersin (Mut) } & \multicolumn{4}{c}{ Konya (Ermenek) } \\
\hline Variables & Min & Max & Mean \pm SE & CV & Min & Max & Mean \pm SE & CV \\
\hline H (cm) & 8.00 & 17.70 & $12.56 \pm 0.21$ & 16.88 & 4.50 & 14.00 & $8.17 \pm 0.17$ & 20.93 \\
RCD (mm) & 1.25 & 3.74 & $2.53 \pm 0.05$ & 21.34 & 1.09 & 3.11 & $2.06 \pm 0.041$ & 19.90 \\
H/RCD & 3.12 & 8.56 & $5.10 \pm 0.10$ & 19.41 & 2.66 & 8.66 & $4.06 \pm 0.10$ & 25.12 \\
RFW (g) & 0.32 & 0.68 & $0.48 \pm 0.07$ & 32.09 & 0.45 & 1.62 & $1.17 \pm 0.25$ & 42.79 \\
SFW (g) & 1.12 & 1.40 & $1.28 \pm 0.66$ & 10.35 & 0.87 & 2.27 & $1.51 \pm 0.31$ & 40.84 \\
SDW (g) & 0.35 & 0.51 & $0.43 \pm 0.035$ & 16.28 & 0.30 & 0.78 & $0.56 \pm 0.11$ & 39.29 \\
RDW (g) & 0.19 & 0.39 & $0.29 \pm 0.045$ & 31.03 & 0.22 & 0.71 & $0.51 \pm 0.11$ & 41.18 \\
SDW/RDW & 1.32 & 2.08 & $1.55 \pm 0.18$ & 23.23 & 0.88 & 1.35 & $1.12 \pm 0.095$ & 16.96 \\
LR & 9.0 & 23.0 & $14.75 \pm 2.95$ & 40.06 & 26.0 & 42.0 & $34.0 \pm 3.26$ & 19.21 \\
SB & 2.0 & 6.0 & $3.75 \pm 0.85$ & 45.54 & - & - & - & - \\
\hline
\end{tabular}

H; Height, RCD; root collar diameter, RFW; root SFW; stem fresh weight, SDW; stem dry weight, RDW; root dry weight, LR; lateral root, SB; side branch, SE; standard Error, CV; coefficient of variation (\%)

Greatest variation occurred for side branch (SB), while the lowest variation is in stem fresh weight (SFW) in Mersin origin and the greatest variation is in RFW, while the smallest variation was found in SDW/RDW in Konya origin at $1+0$ age. The variation coefficient values of the variables (except that RCD, SDW/RDW, and LR) were found to be lower in Mersin origin seedlings than Konya origin seedlings (Table 2).

Table 3. Morphological characteristics of $1+1$ aged and tubed seedlings of Konya and Antalya origins

\begin{tabular}{lcccccccc}
\hline & \multicolumn{4}{c}{ Konya (Ermenek) } & \multicolumn{4}{c}{ Antalya (Kumluca) } \\
\hline Parameters & Min & Max & Mean \pm SE & CV & Min & Max & Mean \pm SE & CV \\
\hline H $(\mathrm{cm})$ & 12.00 & 33.70 & $21.00 \pm 0.47$ & 22.33 & 16.00 & 43.40 & $29.78 \pm 0.46$ & 15.48 \\
RCD $(\mathrm{mm})$ & 2.34 & 7.94 & $5.49 \pm 0.10$ & 18.76 & 2.55 & 7.52 & $5.05 \pm 0.081$ & 16.04 \\
H/RCD & 1.89 & 6.75 & $3.91 \pm 0.09$ & 23.53 & 3.72 & 8.93 & $6.00 \pm 0.11$ & 18.50 \\
RFW $(\mathrm{g})$ & 2.0 & 5.54 & $3.60 \pm 0.82$ & 45.78 & 18.26 & 27.86 & $22.82 \pm 2.52$ & 22.13 \\
SFW(g) & 4.66 & 13.41 & $8.41 \pm 1.85$ & 43.99 & 16.94 & 22.29 & $19.25 \pm 1.12$ & 11.63 \\
SDW(g) & 1.84 & 5.15 & $3.22 \pm 0.71$ & 44.10 & 6.81 & 8.91 & $7.61 \pm 0.47$ & 12.35 \\
RDW(g) & 1.19 & 2.81 & $1.90 \pm 0.39$ & 41.05 & 5.63 & 7.24 & $6.37 \pm 0.43$ & 13.34 \\
SDW/RDW & 1.46 & 1.94 & $1.69 \pm 0.12$ & 13.61 & 0.94 & 1.36 & $1.21 \pm 0.09$ & 14.88 \\
LR & 11.0 & 24.0 & $18.50 \pm 2.78$ & 30.10 & 21.0 & 37.0 & $30.50 \pm 3.40$ & 22.32 \\
SB & 6.0 & 20.0 & $15.0 \pm 3.31$ & 44.22 & 10.0 & 13.0 & $11.50 \pm 0.86$ & 15.06 \\
\hline
\end{tabular}

H; Height, RCD; root collar diameter, RFW; root SFW; stem fresh weight, SDW; stem dry weight, RDW; root dry weight, LR; lateral root, SB; side branch, SE; standard Error, CV; coefficient of variation

Greatest variation occurred for root fresh weight (RFW), while the lowest variation is in stem dry weight/root dry weight ratio (SDW/RDW) in Konya origin and the 
greatest variation is in lateral root (LR), while the smallest variation was found in stem fresh weight (SFW) in Antalya origin at $1+1$ age. The variation coefficient values of the variables (except that SDW/RDW) were found to be lower in Antalya origin seedlings than Konya origin seedlings (Table 3).
Taurus cedar seedlings were compared for same age groups. Measured properties were shown with significance $(\mathrm{P})$ values; $1+0$ age in Mersin - Konya, and 1+1 age in Antalya Konya (Table 4). Besides, mean values of measured properties were shown in Figure 3 and 4 at different origins.

Table 4. Significance $(\mathrm{P})$ values of Taurus cedar seedlings at $1+0$ and $1+1$ age in different origins

\begin{tabular}{lll}
\hline & $1+0$ Mersin/Konya & $1+1$ Antalya/Konya \\
\hline Height & P values & P values \\
Root collar diameter & $0.000^{*}$ & $0.000^{*}$ \\
Height/ Root collar diameter & $0.000^{*}$ & $0.000^{*}$ \\
Root fresh weight & $0.000^{*}$ & $0.000^{*}$ \\
Stem fresh weight & $0.018^{*}$ & $0.000^{*}$ \\
Root dry weight & $0.460^{\mathrm{NS}}$ & $0.000^{*}$ \\
Stem dry weight & $0.057^{\mathrm{NS}}$ & $0.000^{*}$ \\
Root dry weight / Stem dry weight & $0.266^{\mathrm{NS}}$ & $0.000^{*}$ \\
Lateral root & $0.020^{*}$ & $0.008^{*}$ \\
Side branch & $0.000^{*}$ & $0.009^{*}$ \\
\hline
\end{tabular}

*Significant at $5 \%$ level of significance

NS: not significant at $5 \%$ level of significance

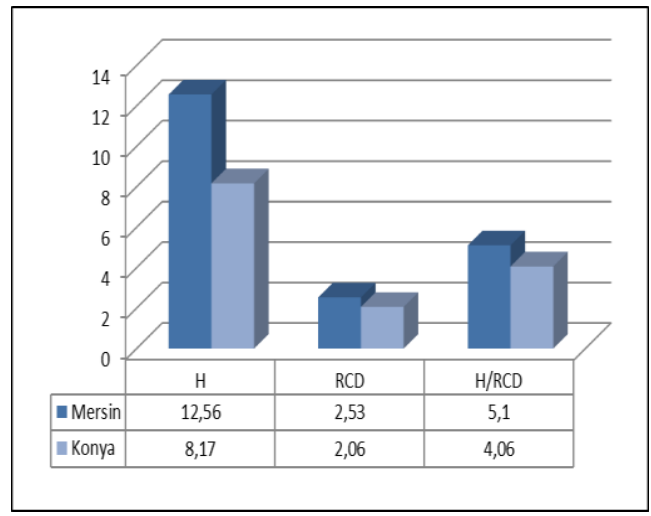

Figure 3. Mean of Taurus cedar seedlings at $1+0$ aged in Mersin and Konya origins

First the morphological characteristics of the seedlings were determined and the appropriateness to Coniferous Trees' Seedling Standards; TS 2265/February 1998 were examined (Anon. 1988). In Konya origin seedlings at $1+0$ age, $54 \%$ of the seedlings as to the seedling height criterion, $67 \%$ of the seedlings as to the root collar diameter criterion were included in first quality class in respect of TSI quality classification. In Antalya and Konya origins, seedlings at $1+1$ age, $100 \%$ of the seedlings as to the seedling height criterion, $100 \%$ of

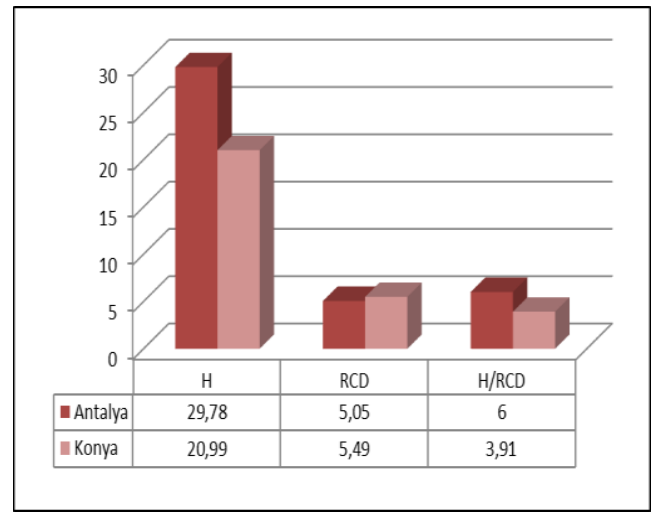

Figure 4. Mean of Taurus cedar seedlings at $1+0$ aged in Antalya and Konya origins

the seedlings as to the root collar diameter criterion were included in first quality class in respect of TSI quality classification. In Mersin origin seedlings at $1+0$ age, $100 \%$ of the seedlings as to the seedling height criterion, $84 \%$ of the seedlings as to the root collar diameter criterion, $100 \%$ of the seedlings as to the stem dry weight /root dry weight ratio criterion were included in first quality class in respect of TSI quality classification (Table 5). 
Table 5. Percent of seedlings meeting height and root-collar diameter criteria of TS2265/ 1988 rating

\begin{tabular}{lccccc}
\hline Age/Origin & \multicolumn{2}{c}{ Height (\%) } & \multicolumn{3}{c}{ Root collar diameter (\%) } \\
& $\mathrm{H} \geq 12 \mathrm{~cm}$ & $10 \leq \mathrm{H}<12 \mathrm{~cm}$ & $\mathrm{H}<10 \mathrm{~cm}$ & $2 \leq \mathrm{RCD}<8 \mathrm{~mm}$ & $\mathrm{RCD}<2 \mathrm{~mm}$ \\
\hline $1+0 /$ Mersin & 100 & - & - & 84 & 16 \\
$1+0 /$ Konya & 54 & 39 & 7 & 67 & 33 \\
$1+1 /$ Konya & 100 & - & - & 100 & \\
$1+1 /$ Antalya & 100 & - & - & 100 & - \\
\hline
\end{tabular}

There was very high positive correlation between root fresh weight and root dry weight $(r=0.988)$ and stem fresh weight with stem dry weight $(r=0.999)$. On the other hand, there was a negative correlation between lateral root and stem dry weight/root dry weight ratio $(\mathrm{r}=-0.616)$, no significant correlation occurred between some variables (Table 6).

Table 6. Results of correlation analysis between measured parameters ( $n=100$ for $H, R C D ; n=4$ for other variables)

\begin{tabular}{|c|c|c|c|c|c|c|c|c|c|c|}
\hline & $\mathrm{H}$ & $\mathrm{RCD}$ & $\mathrm{H} / \mathrm{RCD}$ & LR & SB & RFW & SFW & RDW & SDW & SDW/RDW \\
\hline $\mathrm{H}$ & 1 & & & & & & & & & \\
\hline $\mathrm{RCD}$ & $0.717^{* *}$ & 1 & & & & & & & & \\
\hline $\mathrm{H} / \mathrm{RCD}$ & $0.565^{* *}$ & $0 . \overline{123^{* *}}$ & 1 & & & & & & & \\
\hline LR & $0.539^{* *}$ & $0.502^{* *}$ & 0.208 & 1 & & & & & & \\
\hline SB & -0.087 & 0.052 & $-0.430^{*}$ & 0.119 & 1 & & & & & \\
\hline RFW & $0.716^{* *}$ & $0.662^{* *}$ & 0.227 & 0.106 & 0.127 & 1 & & & & \\
\hline SFW & $0.641^{* *}$ & $0.553^{* *}$ & 0.234 & 0.069 & 0.399 & $0.935^{* *}$ & 1 & & & \\
\hline RDW & $0.666^{* *}$ & $0.695^{* *}$ & 0.091 & $0.398^{*}$ & 0.007 & $0.768^{* *}$ & $0.569^{* *}$ & 1 & & \\
\hline SDW & $0.705^{* *}$ & $0.628^{* *}$ & 0.242 & 0.081 & 0.214 & $0.988^{* *}$ & $0.968^{* *}$ & $0.718^{* *}$ & 1 & \\
\hline SDW/RDW & $0.641^{* *}$ & $0.555^{* * *}$ & 0.232 & 0.071 & 0.385 & $0.942^{* *}$ & $0.999^{* * *}$ & $0.584^{* *}$ & $0.972^{* *}$ & 1 \\
\hline
\end{tabular}

**. Correlation is significant at the 0.01 level (2-tailed).

*. Correlation is significant at the 0.05 level (2-tailed).

$\mathrm{H}$; Height, RCD; root collar diameter, RFW; root SFW; stem fresh weight, SDW; stem dry weight, RDW; root dry weight,

LR; lateral root, SB; side branch

\section{Discussion and Conclusions}

Morphological properties of height, root collar diameter, root dry weight, stem dry weight, and number of lateral roots of Taurus cedar seedlings with different ages and origins were measured and compared in this study.

The $1+0$ aged cedar seedlings of Mersin were greater than those of Konya origin in height, root collar diameter, and height/root collar diameter ratio, while seedlings with Konya origin were greater in that number of lateral root. There were no significant differences between other measured properties. Although $1+1$ old C. libani seedlings of Antalya origin were superior to those of Konya origin in other properties, reverse was true in root collar diameter. Consequently, Antalya and Mersin origin seedlings were better than Konya origin seedlings.

The results obtained from study, which was conducted on $1+0$ and $2+0$ aged Taurus cedar seedlings (Bilir, 1997) were lower than the results of this study. In addition, percentage values of parameters measured in this study were higher than other study according to the quality classification.

In respect of height and root collar diameter in TSI quality classification, the result of seedlings in Mersin origin seems similar to a previous study carried out by 
Alkan (2002). Our study met $100 \%$ of the seedling height criterion, $84 \%$ the root collar diameter criterion, while Alkan (2002) met $100 \%$ of the seedlings used in this study met to the seedling height criterion, $86.67 \%$ the root collar diameter criterion. Avsar (2005)indicated that $C$. libani seedling were included in first quality class.

Demirci and Bilir (2001) suggested that 22 origins were proper in terms of morphological characteristics for the Eastern Black Sea region, according to the results of the origin experiment of three years old Taurus seedlings. Konya-Ermenek origin was one of these origins. However, Antalya and Mersin origins were superior to KonyaErmenek regarding with both of quality classification and measured variables, suggesting that these two origins would be proper for the semi-arid Cankiri region,

Semerci (2005) suggested that "initial seedling morphology is not a good predictor of field survival but root collar diameter. Thus, using seedlings with large diameters in planting might be preferable for the establishment of new plantations to reduce establishment cost. Large diameter seedlings compete well with surrounding vegetation and may gain more biomass in a shorter period than smaller seedlings". Therefore, use of Antalya and Konya origin seedlings that have large diameter can be suggested in reforestation of semi-arid regions of Çankırı.

Morphological properties of seedlings are affected by cultural processes (fertilizing, watering, shading, seedling age, growth media, nursery altitude, undercutting, transplant stock, seedlings density etc.) (Eyüboglu, 1988).

Yazici (2010) studied effect of irrigation on the morphological properties of $2+0$ years old Taurus seedlings at certain days intervals (3, 5, 7 and nursery conditions). The author stated that the best economical interval of irrigation was 7 days, resulting in the first class quality seedlings. In this context, if we have thought the seedlings grown in very humid me dia to have a compliance problem in the semi-arid areas, we can suggest that a certain irrigation interval should be determined for Cankiri region.

\section{References}

Alkan, H. (2002). An important dimension of poor quality: cost increasing (An appraisal in term of the forest tree seedling production). Turkish Journal of Forestry, 2, 97-118.

Anonymous, (1988). Seedling quality classes of the Turkish Standards Institute for coniferous forest tree seedlings. TS 2265/February 1988, 14, Ankara.

Anonymous, (2014). The Seedling production plan of Cankiri Nursery (2014-2018 years). Directorate of Cankiri Forestry Nursery, 18 p. Cankiri.

Anonymous, (2015). The Presence of forest in Turkey. Republic of Turkey Ministry of Forestry and Water Affairs General Directorate of Forestry Publishing, 36 p. Ankara.

Avsar, E. (2005). Containerized seedling characters of some conifer species produced in Kizilcahamam forest nursery. Master Thesis, Gazi University, Graduate School of Natural and Applied Sciences, 108 p. Kastamonu.

Bilir, N. (1997). Nursery stage of provenance on Lebanon cedar (Cedrus libani A. Rich.) in Eastern Black Sea Region. Master Thesis, Karadeniz Technical University, Graduate School of Natural and Applied Sciences, 102 p. Trabzon.

Boydak, M., Calıskan, S. (2014). Afforestation in arid and semi-arid regions. (Editors: Boydak, M., Calıskan, S., Afforestation-Plantation Forestry) OGEM-VAK, 413-444, Istanbul.

Davis, A. S., Jacobs, D. F. (2005). Quantifying root system quality of nursery seedlings and relationship to outplanting performance. New Forests, 30, 295-311.

Demirci, A., Bilir, N. (2001). Provenance variations in 3-year-old Lebanon cedar (Cedrus libani A. Rich.) seedlings. Turkish Journal of Agriculture and Forestry, 25(4), 217-223.

Duryea, M. L. (1985). Evaluating seedling quality: Importance to reforestation, In: Evaluating seedling quality: principles, procedures, and predictive abilities of major tests (Duryea ML, editor) Proceedings of a workshop held October 16-18, 1984, Oregon State University, 
Forest Research Laboratory, Corvallis, 14.

Eken, O. (2015). Seedling quality evaluation of crimean pine and Taurus cedar species in Cankiri (Kenbag) and Eldivan forest nursery. Master Thesis, Cankiri Karatekin University, Graduate School of Natural and Applied Sciences, 156 p. Cankiri.

Eyuboglu, A. K. (1988). Field performance of transplanted and untransplanted oriental spruce (Picea orientalis (L.) Link) seedlings, grown at several bed densities. Directorate of Central Anatolia Forestry Research Institute, Technical Bulletin No: 201, 16 p., Ankara.

Genc, M., Yahyaoglu, Z. (2007). Properties and Determination Used in Quality Classification. (Editors: Yahyaoglu, Z. and M. Genç, Seedling Standardization) Suleyman Demirel University Faculty of Forestry Publications, Publication No: 75, 355-465, Isparta.

Mattsson, A. (1996). Predicting field performance using seedling quality assessment. New Forests, 13(1-3), 227252.

Mexal, J. G., Landis T. D. (1990). Target seedling concepts: height and diameter. (Editors: Rose R, Campbell S. J. and Landis T. D., Target seedling symposium, Combined meeting of the Western Forest Nursery Associations. USDA Forest Service, Rocky Mountain Forest and Experiment Station, Gen. Tech. Rep. RM-200), 17-35.

Semerci, A. (2005). Fifth year performance of morphologically graded Cedrus libani seedlings in the Central Anatolia Region of Turkey. Turkish Journal of Agriculture and Forestry, 29, 483-491.

Thompson B. E. (1985). Seedling morphological evaluation-what you can tell by looking. In: Evaluating seedling quality: principles, procedures, and predictive abilities of major tests. (Editor: Duryea M. L., Proceedings Evaluating Seedling Quality: Principles, Procedures, and Predicitive Abilities of Major Tests) Oregon State University, Corvallis, 59-71.

Urgenc, S. (1986). Afforestation technique. Istanbul University Faculty of Forestry Publication, Publication No: 375, Istanbul.
Yahyaoglu, Z., Genc, M. (1990). Breeding studies in cedar (Cedrus libani A. Rich.), Proc. International Cedar Symposium, 22-27 Oct. 1990, Antalya, Directorate of Central Anatolia Forestry Research Institute, Miscellaneous Publications, Publication No. 59, 325-333.

Yazici, N. (2010). Determination of water consumption of some coniferous seedlings and its relation with meteorological parameters. Doctoral Thesis, Suleyman Demirel University, Graduate School of Natural and Applied Sciences, 112 p. Isparta 